\title{
Occurrence of anti-Neospora caninum antibodies in cattle in the dairy farming region of the state of Piauí, Brazil
}

\author{
Ocorrência de anticorpos anti- Neospora caninum em vacas na bacia leiteira do estado do Piauí, Brasil \\ Raylson Pereira de Oliveirai*; Nínivy Marques Soares ${ }^{2}$; José Givanildo da Silva ${ }^{1}$; Müller Ribeiro-Andrade'; \\ Nair Silva Cavalcanti de Lira²; Márcia Paula Oliveira Farias²; Rinaldo Aparecido Mota ${ }^{1}$
}

\begin{abstract}
${ }^{1}$ Departamento de Medicina Veterinária, Universidade Federal Rural de Pernambuco - UFRPE, Recife, PE, Brasil
${ }^{2}$ Departamento de Medicina Veterinária, Universidade Federal do Piauí - UFPI, Campus Professora Cinobelina Elvas,

Bom Jesus, PI, Brasil
\end{abstract}

Received March 14, 2018

Accepted May 16, 2018

\begin{abstract}
This study focused on the detection of anti-Neospora caninum IgG antibodies in cows in the dairy farming region of the state of Piauí, Brazil. To this end, serum samples were collected from 255 dairy cows on 17 farms located in the dairy farming region of the municipality of Parnaíba, Piauí, Brazil. The indirect fluorescence antibody test (IFAT) was employed to detect anti- $N$. caninum $\operatorname{IgG}$ antibodies, using anti-bovine $\operatorname{IgG}\left(\mathrm{Sigma}^{\circ}\right)$ conjugated to fluorescein isothiocyanate (FITC) and a cutoff point of 1:200. Of the 255 samples analyzed, $69(27.06 \%)$ were positive for anti- $N$. caninum IgG antibodies, the relative frequency found by property was: $1(20.00 \%), 2(53.33 \%), 3(46.66 \%), 4(53.33 \%), 5(26.66 \%)$, 6 (6.66\%), 7 (6.66\%), 8 (20.00\%), 9 (26.66\%), 10 (26.66\%), 11 (20.00\%), 12 (20.00\%), 13 (46.66\%), 14 (26.66\%), $15(26.66 \%), 16(20.00 \%)$ and $17(13.33 \%)$. with titers of 200 (15.94\%), $400(20.30 \%), 800(24.63 \%), 1600(23.18 \%)$ and $3200(15.94 \%)$, being the highest frequency for the titer of 800 . This study demonstrates for the first time that cows from dairy herds of Parnaíba municipality, state of Piauí, are exposed to N. caninum.
\end{abstract}

Keywords: Cattle, neosporosis, indirect immunofluorescence reaction.

\section{Resumo}

Objetivou-se estudar a ocorrência de anticorpos IgG anti- Neospora caninum em vacas, na bacia leiteira do estado do Piauí, Brasil. Foram obtidas amostras séricas de 255 vacas leiteiras provenientes de 17 propriedades localizadas na bacia leiteira do município de Parnaíba, Piauí, Brasil. Para a pesquisa de anticorpos IgG anti- N. caninum foi empregada a técnica de Reaçáo de Imunofluorescência Indireta, utilizando-se conjugado anti-IgG bovine (Sigma ${ }^{\circ}$ ) conjugado ao isotiocianato de fluoresceína e ponto de corte 1:200. Das 255 amostras analisadas, 69 (27,06\%) foram positivas para anticorpos IgG anti- $N$. caninum, a frequência relativa encontrada por propriedade foi de: $1(20,00 \%), 2(53,33 \%), 3(46,66 \%), 4$ (53,33\%), 5 (26,66\%), 6 (6,66\%), 7 (6,66\%), 8 (20,00\%), 9 (26,66\%) 10 (26,66\%), $11(20,00 \%), 12(20,00 \%), 13$ (46,66\%), 14 (26,66\%), 15 (26,66\%), $16(20,00 \%)$ e $17(13,33 \%)$ com títulos de 200 (15,94\%), 400 (20,30\%), 800 (24,63\%), $1600(23,18 \%)$ e $3200(15,94 \%)$, sendo a maior frequência para o título de 800 . Este estudo demonstra pela primeira vez que, vacas de rebanhos leiteiros do município de Parnaíba, estado do Piauí, estão expostas ao $N$. caninum.

Palavras-chave: Bovinos, neosporose, reação de imunofluorescência indireta.

\section{Introduction}

Neosporosis is a significant protozoan disease of domestic animals and an emerging parasitic disease worldwide. It is caused by the apicomplexan parasite Neospora caninum. Definitive hosts of $N$. caninum include the domestic dog (Canis lupus familiaris) (MCALLISTER et al., 1998), the coyote (Canis latrans)

*Corresponding author: Raylson Pereira de Oliveira. Departamento de Medicina Veterinária, Universidade Federal Rural de Pernambuco - UFRPE, Rua Dom Manoel de Medeiros, s/n, Dois Irmãos, CEP 52171-900, Recife, PE, Brasil. e-mail: raylson.oliveira@hotmail.com.br
(GONDIM et al., 2004), the Australian dingo (Canis lupus dingo) (KING et al., 2010), and the gray wolf (Canis lupus) (DUBEY et al., 2011). Domestic and wild mammals are the intermediate hosts of this protozoan organism (DUBEY et al., 2007).

Neosporosis causes major production and reproduction losses to the livestock industry, especially in cattle farming. Cows infected with $N$. caninum experience irregular estrous cycles or return to estrus, abortions, and neonatal deaths (DUBEY; SCHARES, 2011). With regard to the economic impact of bovine neosporosis, fetal deaths 
and the culling of cows that are serologically positive for $N$. caninum have been reported (HEIN et al., 2012; REICHEL et al., 2013).

The global occurrence of $N$. caninum infection makes this infectious disease one of the main obstacles faced by animal production, especially for the dairy cattle industry. Prevalence rates of neosporosis in cattle may vary depending on the presence of definitive hosts in one particular geographic region and according to environmental factors in each country such as high humidity and high rainfall (DUBEY et al., 2007).

Over the years, many studies about the seroprevalence of bovine neosporosis have been published by researchers from different parts of the world in which seropositivity rates have varied between $0.7 \%$ in Norway (KLEVAR et al., 2010) and 97.2\% in Brazil (GUEDES et al., 2008).

Serological surveys were performed in all regions of Brazil such as Minas Gerais (GUEDES et al., 2008), Santa Catarina (LORENZETT et al., 2016), Pará (MINERVINO et al., 2008), Mato Grosso (BENETTI et al., 2009), Bahia (GONDIM et al., 1999) and Pernambuco (SILVA et al., 2014). To date, there is only one published serological study of $N$. caninum infection in cattle in the state of Piauí in the northeastern region of the country. The survey was carried out in the microregion of the city of Teresina. The frequency of anti- $N$. caninum antibodies in the herds tested was 15.23\% (CAVALCANTE et al., 2015).

Given the paucity of information on bovine neosporosis in the dairy farming region of the state of Piauí, our objective was to study the occurrence of anti-Neospora caninum antibodies in dairy cows in the municipality of Parnaíba, Piauí, Brazil.

\section{Materials and Methods}

\section{Study area}

The dairy farming area of the state of Piauí, northeast Brazil, is located in the county of Parnaíba, in the coast of the state, at $2^{\circ} 54$ ' 14 " South latitude, and 41 $46^{\prime \prime} 35^{\prime \prime}$ West longitude. Approximately 40,000 liters of milk are produced per day in this geographic area. It has an excellent infrastructure which is used by several milk producing counties in the northern part of the state (ARAGÃO et al., 2012).

\section{Sampling}

In this study, a non-probability sampling technique was used for the sake of convenience (SAMPAIO, 1998). In the present survey, serum samples from lactating Girolando cows were tested for the presence of $N$. caninum antibodies. These were animals from rural and urban semi-intensive breeding systems located in the county of Parnaíba, where dairy farms of the state of Piauí are located. Samples from 17 farms were analysed. Each farm was provided with a number, i.e. Farm 1 to Farm 17. Serum specimens from 15 animals of each farm were tested. A total of 255 cows were evaluated. The lateral neck of each cow was cleaned with tincture of iodine (antiseptic solution of iodine and alcohol) to disinfect the venipuncture site. Blood was drawn from the jugular vein.
Serum samples were stored in Eppendorf tubes. These specimens were kept frozen until analysed. During the visits to these dairy farms for sample collection, producers received a questionnaire with questions about the presence of dogs in the premise and the occurrence of abortions in the herd.

\section{Serological testing}

Serum samples were tested by the indirect fluorescent antibody testing (IFAT) for the presence of IgG anti- $N$. caninum antibodies according to the protocol published by Dubey et al. (1988). Anti-bovine IgG (Sigma ${ }^{\oplus}$ ) conjugated to fluorescein isothiocyanate (FITC) was used in this assay; 1:200 was the cut-off point established to define test positivity (GONDIM et al., 1999). Slides were sensitized with $N$. caninum tachyzoites (Nc-Spain7 isolate) (REGIDOR-CERRILLO et al., 2008) maintained in cell culture (MARC-145 cells). This cell line was cultivated at the Laboratory of Infectious and Contagious Diseases of Domestic Animals of the Federal Rural University of Pernambuco (UFRPE) located in the city of Recife, State of Pernambuco, northeast Brazil. Serum samples from naturally infected cattle tested by IFAT and ELISA for the presence of $N$. caninum antibodies in a previous study were used in the present survey as positive and negative controls.

For positive samples, serial dilutions were performed from the initial dilution of 1:200 up to the dilution of 1:3200.

\section{Ethical considerations}

All research procedures were approved by the Ethics Committee on Animal Use in Research of the Federal Rural University of Pernambuco (CEUA-UFRPE; License no. 119/2017).

\section{Results}

The IFAT revealed that $27.06 \%(69 / 255)$ of the samples in this study contained anti- $N$. caninum IgG antibodies. In relation to the distribution of positive animals there was a considerable variation between the properties with frequencies varying from 6.66\% (properties 6 and 7) to 53.66\% (properties 2 and 4) of positive animals, the relative frequency found by property was: 1 (20.00\%), 2 (53.33\%), 3 (46.66\%), 4 (53.33\%), 5 (26.66\%), $6(6.66 \%), 7$ (6.66\%), 8 (20.00\%), 9 (26.66\%), $10(26.66 \%)$, 11 (20.00\%), 12 (20.00\%), 13 (46.66\%), 14 (26.66\%), 15 (26.66\%), $16(20.00 \%)$ and $17(13.33 \%)$. Antibody titers varied among the studied herds, with a distribution of $200(11 / 69,15.94 \%)$, 400 (14/69, 20.30\%), 800 (17/24.63, 24.63\%), 1600 (16/69, $23.18 \%)$ and $3200(11 / 69,15.94 \%)$, with the highest frequency observed for the titer of 800 .

Even with the abortions being considered endemic in all herds in this study, in the properties that had animals with higher antibody titers, no outbreaks of abortion were reported. The history of abortion and presence of dogs associated with infection by $N$. caninum was not statistically analyzed by logistic regression in the risk analysis, since in all properties these events were reported. 


\section{Discussion}

In the present survey, the detection of cows seropositive for $N$. caninum by IFAT in all herds tested demonstrates that neosporosis has spread throughout the study area. In this study, 44 animals had titers ranging from 800 to 3200 . Titers equal to or greater than 800 are considered high, suggesting active N. caninum infection (DUBEY, 1999; LINDSAY et al., 1999). All the properties studied had history of abortion or recurrence of estrus, indicating a possible participation of the congenital pathway in the transmission of this protozoan in these properties, and new studies are necessary to determine the real participation of this pathway in the infection by the parasite.

The frequency of seropositive animals in our study - $27.06 \%$ - was higher than the one reported by Cavalcante et al. (2015). These researchers used IFAT to detect anti- $N$. caninum antibodies, and adopted an initial cut-off value of 1:200; 15.23\% (64/420) of the animals from the microregion of Teresina, State of Piauí, northeast Brazil, were seropositive for $N$. caninum. These findings show that the frequency of animals infected with this protozoan organism may vary in different parts of the same Brazilian state.

Similar results were obtained in seroepidemiological surveys about bovine neosporosis carried out by Silva et al. (2008) and Silva et al. (2014). In the studies conducted by Silva et al. (2008, 2014) in different areas of the state of Pernambuco, northeast region of the country, $31.7 \%$ and $6.4 \%$ of the serum samples from cows were positive for $N$. caninum, respectively. In both studies, the same assay - IFAT - and cut-off point - 1: 200 - were used.

In other regions of Brazil, lower frequencies of neosporosis were observed in cattle, e.g. in the studies conducted by Lorenzett et al. (2016) in the state of Santa Catarina, south Brazil (7.7\%), and by Aguiar et al. (2006) in the state of Amazonas (10.6\%), northern region of the country. However, other studies have found higher frequencies of bovine neosporosis including those carried out in central-west Brazil in the states of Goiás (30.4\%) (MELO et al., 2006) and Mato Grosso (53.5\%) (BENETTI et al., 2009).

In the Northeast region of Brazil, there are reports of infection by caused $N$. caninum in cattle in almost all states, such as Bahia (14.1\%) (GONDIM et al., 1999), Maranhão (50.74\%) (TEIXEIRA et al., 2010), Alagoas (7.67\%) (SOUSA et al, 2012), Pernambuco (6.4\%) (SILVA et al., 2014), Piauí (15.23\%) (CAVALCANTE et al., 2015) and recently in the state of Paraíba (12.27\%) (MELO et al., 2017). However, in Piauí state there was still no report of the occurrence of this parasite in cows in the state dairy.

The reports of abortion and repetition of estrus, associated with the positive serology and animals with high antibody titers, indicate that this parasite is circulating on these farms and that it should be included in the differential diagnosis of abortion in cattle.

\section{Conclusions}

This study demonstrates for the first time that cows from dairy herds of Parnaíba municipality, state of Piauí, are exposed to $N$. caninum infection.

\section{References}

Aguiar DM, Cavalcante GT, Rodrigues AA, Labruna MB, Camargo LMA, Camargo EP, et al. Prevalence of anti-Neospora caninum antibodies in cattle and dogs from Western Amazon, Brazil, in association with some possible risk factors. Vet Parasitol 2006; 142(1-2): 71-77. http://dx.doi. org/10.1016/j.vetpar.2006.06.014. PMid:16857319.

Aragão FJM, Bonfim MRQ, Vieira AF, Souza FAL, Bezerra EEA, Mineiro ALBB. Avaliaçâo e comparação entre as reações de soroaglutinação microscópica e o ensaio imunoenzimático (ELISA igG), com o antígeno recombinante LipL32 para o diagnóstico da leptospirose bovina [online]. Teresina: UFPI; 2012 [cited 2018 Mar 3]. Available from: http://leg.ufpi.br/20sic/Documentos/ RESUMOS/Modalidade/Exatas/f016e59c7ad8b1d72903bb1aa5720d53.pdf

Benetti AH, Schein FB, Santos TR, Toniollo GH, Costa AJ, Mineo $\mathrm{JR}$, et al. Pesquisa de anticorpos anti-Neospora caninum em bovinos leiteiros, cães e trabalhadores rurais da região Sudoeste do Estado de Mato Grosso. Rev Bras Parasitol Vet 2009;18(Suppl 1): 29-33. http:// dx.doi.org/10.4322/rbpv.018e1005. PMid:20040187.

Cavalcante RG, Santos JCP, Rebelo PHV, Oliveira FS, Soares RA, Feitosa FS Jr, et al. Prevalência e fatores de risco da neosporose bovina na microrregiáo de Teresina, PI: resultados preliminares. Arq Inst Biol 2015; 77(S2): 27.

Dubey JP, Hattel AL, Lindsay DS, Topper MJ. Neonatal Neospora caninum infection in dogs: isolation of the causative agent experimental transmission. J Am Vet Med Assoc 1988; 193(10): 1259-1263. PMid:3144521.

Dubey JP, Jenkins MC, Rajendran C, Miska K, Ferreira LR, Martins J, et al. Gray wolf (Canis lupus) is a natural definitive host for Neospora caninum. Vet Parasitol 2011; 181(2-4): 382-387. http://dx.doi.org/10.1016/j. vetpar.2011.05.018. PMid:21640485.

Dubey JP, Schares G, Ortega-Mora LM. Epidemiology and control of Neosporosis and Neospora caninum. Clin Microbiol Rev 2007; 20(2): 323-367. http://dx.doi.org/10.1128/CMR.00031-06. PMid:17428888.

Dubey JP, Schares G. Neosporosis in animals: the last five years. Vet Parasitol 2011; 180(1-2): 90-108. http://dx.doi.org/10.1016/j.vetpar.2011.05.031. PMid:21704458.

Dubey JP. Recent advances in Neospora and neosporosis. Vet Parasitol 1999; 84(3-4): 349-367. http://dx.doi.org/10.1016/S0304-4017(99)00044-8. PMid:10456423.

Gondim LF, McAllister MM, Pitt WC, Zemlicka DE. Coyotes (Canis latrans) are definitive hosts of Neospora caninum. Int J Parasitol 2004; 34(2): 159-161. http://dx.doi.org/10.1016/j.ijpara.2004.01.001. PMid:15037103.

Gondim LF, Sartor IF, Hasegawa M, Yamane I. Seroprevalence of Neospora caninum in dairy cattle in Bahia, Brazil. Vet Parasitol 1999; 86(1): 71-75. http://dx.doi.org/10.1016/S0304-4017(99)00129-6. PMid:10489205.

Guedes MHP, Guimarães AM, Rocha CMBM, Hirsch C. Frequência de anticorpos anti-Neospora caninum em vacas e fetos provenientes de municípios do sul de Minas Gerais. Rev Bras Parasitol Vet 2008; 17(4): 189-194. http://dx.doi.org/10.1590/S1984-29612008000400004. PMid:19265576.

Hein HE, Machado G, Miranda ICS, Costa EDF, Pellegrini DCP, Driemeier D, et al. Neosporose bovina: avaliação da transmissão vertical e fração atribuível de aborto em uma populaçáo de bovinos no Estado do Rio Grande do Sul. Pesq Vet Bras 2012; 32(5): 396-400. http://dx.doi. org/10.1590/S0100-736X2012000500006. 
King JS, Šlapeta J, Jenkins DJ, Al-Qassab SE, Ellis JT, Windsor PA. Australian dingoes are definitive hosts of Neospora caninum. Int J Parasitol 2010; 40(8): 945-950. http://dx.doi.org/10.1016/j.ijpara.2010.01.008. PMid:20149793.

Klevar S, Norström M, Tharaldsen J, Clausen T, Björkman C. The prevalence and spatial clustering of Neospora caninum in dairy herds in Norway. Vet Parasitol 2010; 170(1-2): 153-157. http://dx.doi.org/10.1016/j. vetpar.2010.02.005. PMid:20227188.

Lindsay DS, Upton SJ, Dubey JP. A structural study of the Neospora caninum oocyst. Int J Parasitol 1999; 29(10): 1521-1523. http://dx.doi. org/10.1016/S0020-7519(99)00121-6. PMid:10608437.

Lorenzett MP, Lucca NJ, Henker LC, Machado G, Gomes DC, Mendes RE, et al. Ocorrência de anticorpos anti-Neospora caninum em bovinos leiteiros no oeste do estado de Santa Catarina, Brasil. Rev Bras Med Vet 2016; 38(3): 243-249.

McAllister MM, Dubey JP, Lindsay DS, Jolley WR, Wills RA, McGuire AM. Dogs are definitive hosts of Neospora caninum. Int J Parasitol 1998; 28(9): 1473-1478. http://dx.doi.org/10.1016/S0020-7519(98)00138-6. PMid:9770635.

Melo DPG, Da Silva AC, Ortega-Mora LM, Bastos SA, Boaventura CM. Prevalência de anticorpos anti-Neospora caninum em bovinos das microrregióes de Goiânia e Anápolis, Goiás, Brasil. Rev Bras Parasitol Vet 2006; 15(3): 105-109. PMid:16978474.

Melo LRB, Feitosa TF, Vilela VLR, Athayde ACR, Azevedo SS, Jesus Pena HF. Seroprevalence of Neospora caninum in dairy cattle and dogs from the Agreste region of the State of Paraíba. Acta Vet Bras 2017; 11(1): 57-62. http://dx.doi.org/10.21708/avb.2017.11.1.6677.

Minervino AHH, Ragozo AMA, Monteiro RM, Ortolani RL, Gennari SM. Prevalence of Neospora caninum antibodies in cattle from Santarém,
Pará, Brazil. Res Vet Sci 2008; 84(2): 254-256. http://dx.doi.org/10.1016/j. rvsc.2007.05.003. PMid:17619028.

Regidor-Cerrillo J, Gómez-Bautista M, Pereira-Bueno J, Aduriz G, NavarroLozano V, Risco-Castillo V, et al. Isolation and genetic characterization of Neospora caninum from asymptomatic calves in Spain. Parasitology 2008; 135(14): 1651-1659. http://dx.doi.org/10.1017/S003118200800509X. PMid:18980700.

Reichel MP, Alejandra Ayanegui-Alcérreca M, Gondim LF, Ellis JT. What is the global economic impact of Neospora caninum in cattle: the billion dollar question. Int J Parasitol 2013; 43(2): 133-142. http://dx.doi. org/10.1016/j.ijpara.2012.10.022. PMid:23246675

Sampaio IBM. Estatística aplicada à experimentação animal. Belo Horizonte: FEPMVZ; 1998. 221 p.

Silva JG, Guerra NR, Melo RPB, Albuquerque PPF, Alves LC, Mota RA. Ocorrência de anticorpos IgG anti-Neospora caninum em vacas leiteiras no estado de Pernambuco, Brasil. Ciênc Vet Tróp 2014; 17(1-2): 30-35.

Silva MIS, Almeida MÂO, Mota RA, Pinheiro-Junior JW, Rabelo SSA. Fatores de riscos associados à infecção por Neospora caninum em matrizes bovinas leiteiras em Pernambuco. Cienc Anim Bras 2008; 9(2): 455-461.

Sousa ME, Wagnner JNP, Albuquerque PPF, Souza OL No, Faria EB, Pinheiro JW Jr, et al. Seroprevalence and risk factors associated with infection by Neospora caninum of dairy cattle in the state of Alagoas, Brazil. Pesq Vet Bras 2012; 32(10): 1009-1013. http://dx.doi.org/10.1590/ S0100-736X2012001000011

Teixeira WC, Uzêda RS, Gondim LFP, Silva MIS, Pereira HM, Alves LC, et al. Prevalência de anticorpos anti-Neospora caninum (Apicomplexa: Sarcocystidae) em bovinos leiteiros de propriedades rurais em três microrregiōes no estado do Maranhão. Pesq Vet Bras 2010; 30(9): 729734. http://dx.doi.org/10.1590/S0100-736X2010000900004. 